\title{
Aniztasun erlijiosoa: zer eta nolako informazioa
}

\author{
Religious diversity: \\ What information and what kind \\ Luzio Uriarte González·luzio.uriarte@deusto.es \\ Gorka Urrutia Asua·gorka.urrutia@deusto.es \\ DEUSTUKO UNIBERTSITATEA
}

Recibido: 04-04-2016

Aceptado: 18-05-2016

\section{Laburpena}

Erlijioa eta talde erlijiosoak sarri askotan albiste bihurtzen dira, giro sekularizatuan hedabide gehienek kontu erlijiosoetan aparteko interesik ez izan arren. Baina albisteen kontsumoaren logikan, erlijio kontuek merkatu zabala dute zenbaitetan, batez ere eskandalu, ezohiko jarduera, gatazka eta bortizkeria kasuak gertatzean. Joan den mendeko 60ko hamarkadatik aurrera, testuinguru soziala eta instituzionala nabarmen sekularizatua da euskal gizartean, eta begien bistakoa da belaunaldien arteko ikaragarrizko jauzia; sekularizazioaren prozesua gertatu baino lehen zein gertatu ondoren, katolizismoarekin lotuak ez dauden gutxiengo erlijiosoak sozialki ikusezinak izan dira, oro har. Berriki, eta hainbat arrazoi tarteko direla, aniztasun erlijiosoa agerikoago bilakatu denean, hedabideetan aztergai bihurtu da gero eta sarriagotan.

Hedabideek gutxiengo erlijiosoei eskaintzen dieten arreta eta tratamendua oso esanguratsua da talde horientzat, baita gizartearen iritziak eta jarrerak eraikitzean eta zabaltzean ere. Hori kontuan izanik, artikulu honetan jasotzen dugu gutxiengo erlijiosoen ikuspuntua eta eskarmentua hedabideekin, hots, nola atzematen duten bere egoeraren eta errealitatearen tratamendua albisteetan. Euskal Autonomia Erkidegoan, eta gai honen inguruan, gutxiengo erlijioso ia guztiekin hainbat elkarrizketa eta talde-bilera egin ondoren, kezken zerrenda bat osatu dugu, gai nagusiak ondorengoak izanik: ikusezintasuna, oso gauza bitxia gertatu ezean, ez baitira inoiz berri; albiste-iturri bihurtzean, informazioak ñabardura negatiboz kutsatuak izatea; datuen eta adierazpenen esanahia ez errespetatzea; gai erlijiosoan adituak ez izanik, hiztegia eta zenbait azalpen zehatzak ez izatea; informazioa eta aurreiritziak nahasita agertzea sarri askotan.

Gure lanaren azken partean, funtsezko galdera planteatzen dugu: badago oinarririk kezka horietan? Galdera horri heltzeko, bertako zenbait hedabideren (Vocento Taldearenak, Gara, Deia, Berria) azken bost urteotako jarduera aztertu dugu, baita gai honetaz komunikabideen jarduera jarraitzen duten behatokien informazioa ere.

Hitz gakoak: Hedabideak, gutxiengo erlijiosoak, aniztasun erlijiosoa, Gizarte sekularizatua, erlijioa

\section{Abstract}

Religion and religious groups often become news, even though the means of communication secularized not show greater interest in religious issues. However, in a logic of news consumption, religious issues have a large market. Especially scandals, conflicts and violence cases. Since the 60 s, the social and institutional context have been secularized significantly in Basque society and the generation gap is evident. Before and after that secularization process, ethnic minorities unrelated to Catholicism were practically invisible. Recently, and for various reasons, when religious diversity has become evident, it manifests itself increasingly in the media.

The attention that the media show religious minorities the treatment given have much influence on the group itself, the opinion of the population and the development of attitudes. Considering the above, in this article we collect the point of view of religious minorities and their experience with the media, how they represent their situation and reality. In the Basque Country, regarding to this, after doing interviews and focus groups with religious minorities, we have developed a list of concerns. The main points of this list are: invisibility, unless something particular happened it does not become new; When they become news, information has a negative undertone; no respect for data and manifestations, vocabulary and explanations are not adequate; often the information and opinions are mixed.

In the last part of this work, we make ourselves a fundamental question: Is it a concern with real basis? To answer this question we have analyzed several media (Vocento Taldearenak, Gara, Deia, Berria) in the last 5 years.

Key words: Mass media, religious minorities, religious diversity, religious minorities, religion 


\section{SARRERA}

Urte askoan eta euskal gizartearen eguneroko bizitzan, edozein elkarrizketaren harira, erlijioaren kontua azaltzen bazen, elkarrizketako partaide guztiek, inkontzienteki bazen ere, kristautasun katolikoaz, zehatzago, Eliza katolikoaz ari zela ulertu ohi zuten. Hau da, erlijioaren eta kristautasun katolikoaren arteko nolabaiteko identifikazioa gertatzen zen herritar arrunten imajinario kolektiboan. Hala ere, sinesmen erlijiosoei dagokienez, gizartea ez da inoiz homogeneoa izan, ezta bi taldek osatua ere -katolikoek sinestedun ez zirenek, alegia-; aitzitik, historian zehar, gure gizartea beti izan da askotarikoa, kontzientzia kolektiboan eta agertoki publikoan irudikatu dena baino askoz gehiago. Hemen aztergai ez diren zenbait arrazoirengatik, aniztasun erlijiosoa agerikoa ez bazen ere, irudikatutako homogeneotasun horren azpian ezkutua bizi zen -agian hobeto, bizirik zirauen-, baina ikusiezina herritar gehienentzat.

Azken bi hamarkadetako egoera, berriz, ez dator bat esandakoarekin, gero eta argiago ikusi baita tradizio katolikoaren gainbeherak ez dakarrela erlijioa desagertzea edo bazter ilun batean geratzea; aniztasun erlijiosoa gero eta nabariagoa da jendearen pertzepzioan, gehiengo batentzat kontu harrigarria bada ere. Aldaketa ez da iraultza bat izan, paisaia soziala ez da goitik behera aldatu goizetik gauera; alderantziz baino, aldaketa progresiboa izan da, gero eta nabariagoa. Oraindik ere, zabalik dagoen prozesu batez mintzatzen ari gara, zeinek zer ibilbide eta etorkizuna izango duen asmatzea zaila den.

Egitate erlijiosoari buruzko ikusmiraren eta balorazioaren aldaketa horren azpian zenbait arrazoi egon daitezke. Lehenik, mundu guztian zehar, gizarte garatuetan barne, erlijioaren iraupenak eta, zenbaitetan, hedapenak birpentsarazi du gizarte garatu, sekularizazio eta erlijio aldagaien arteko ekuazioa (Casanova, 2000; Habermas, 2006; Mardones 1998; Urrutia, 2015). Bigarrenik, agian aurreko datuarekin lotua neurri batean, erlijioaren eta laikotasunaren arteko lokarriak birplanteatuak izan dira zenbait pentsalariren gogoetan (Taylor, 2010). Hirugarrenik, gure esperientzia hurbilari begiratuta, argi dago gure artean tradizio erlijioso berriak agertu direla ${ }^{1}$; horrekin batera, erlijioaren presentzia publikoa eta aniztasun erlijiosoa ordenatzeko lege esparrua eta hori guztia kudeatzeko arauak ez daude gaurkoturik, zenbait arazotan ikusi ahal izan denez (Eusko Jaurlaritza, 2015).

Azken hamarkadan, Euskal Autonomia Erkidegoko aniztasun erlijiosoari buruzko zenbait ikerketa egiteko aukera izan dugu, gehienbat gutxiengo erlijiosoek parte hartze normalizatua izan dezaten gizartean eta, horrekin batera, inolako bidegabeko diskriminaziorik jasan ez dezaten. Lehenengo pausoa talde erlijioso horien mapa osatzea izan bazen ere (Ruiz Vieytez, 2010), hainbat banako elkarrizketa eta talde-eztabaida izan eta gutxiengo erlijiosoen ikuspuntua jaso ondoren, aniztasun horren beste zenbait alde ikertu beharra zegoela argi ikusi genuen (Ruiz Vieytez, 2011; Ruiz Vieytez eta Morondo, 2014).

${ }^{1}$ Berriak, ez historikoki agertu berriak diren zentzuan, gure lurraldean ezezagunak ziren zentzuan baizik. 
Besteak beste, ikerketa horien harira eta egindako elkarrizketen testuinguruan, hedabideen rola eta jokabidea zein zen agertu zitzaigun sarri askotan; hori guztiz ulergarria da, hedabideen eragina eta botere soziala inor gutxik jarriko baitu zalantzan. Gaurko testuinguru kulturalak baldintzaturik, bere ibilbide soziala egiten dute gutxiengo erlijiosoek, eraikuntza sozialean parte hartu nahirik. Baldintza horien artean, zalantzarik ez, gizartearen ezaugarriekin batera, hedabideen portaera eta jarrera ditugu.

Gutxiengo erlijiosoek komunikazio sozialean erakusten duten interesa eta kezka abiapuntutzat hartuz, artikulu honetan planteatzen ditugun helburuak hurrengoak dira:

- Lehenengo eta behin, talde horien interes eta estrategia komunikatibora hurbiltzea.

- Bigarrenik, komunikabide sozial handietan oso eragin eskasa dutela kontuan izanik, gutxiengo erlijiosoek beraiei buruzko informazioa komunikabideetan nola balioesten duten jasotzea.

- Hirugarrenik, gutxiengo erlijiosoen kritika kontuan izanik, azken urteetako prentsa idatzian kritika horiek nolabaiteko oinarririk duten aztertzea.

Helburu horiei heltzeko, azken urte hauetako ikerketa-jardueran gutxiengo erlijiosoekin izandako elkarrizketak dira gure lanaren oinarrizko materiala, gure ibilbidearen abiapuntua. Elkarrizketa horiek arakatuz, komunikazio soziala bilatzean, talde horien planteamendua eta estrategia jasotzen dugu. Hala ere, espero bezala, talde horiek, bere baliabideetan oinarrituta, oso aukera gutxi dute komunikazio eraginkorra izateko; hots, gehienbat, komunikabide handien politikaren menpean daude. Hori dela-eta, hemen gutxiengo erlijiosoen ikuspuntu kritikoa interesatzen zaigu gehien, hots, hedabideetan taldeok informazio-gai bihurtzen direnean, informazio hori nola balioesten duten. Elkarrizketetan agertzen diren kritika horiek aletu, sailkatu eta aurkezten ditugu. Talde horien kritikak oinarririk ote duen ikuste aldera, azken bost urteko zenbait egunkari aztertu ditugu, EAEn irismen handienekoak, hizkuntza ere kontuan izanik.

Gaia dela-eta, gure lanaren helburua ez bada ere, garrantzitsu iruditu zaigu beste bi gogoeta kontuan izatea, hasieran planteatzen ditugunak, hain zuzen: hedabideen funtzioak eta erlijioaren esanahi soziala. Bi puntu horiek ondo jorratzeak artikulu oso bat eskatuko luke; ez da hori gure asmoa, baina gure gaia aurkeztean, nolabait kontuan izan behar ditugu, besterik gabe bada ere, erreferentzia xume bat eginez.

\section{ATARIKO ELEMENTUAK}

Gutxiengo erlijiosoen komunikazio sozialari heltzean -bai talde horiek zuzenean kontrolatutakoari, bai hedabideek kudeatutakoari-, atariko bi elementu kontuan izan behar ditugu, biek ala biek gure gaia baldintzatzen baitute: errealitate sozialaren definizioan hedabideen zeregina eta erlijioaren esanahi soziala. Esanda dagoen bezala, azaleko aipamen bana baino ezin dugu egin idazki honetan, gure gogoeta baldintzatu arren, ez baitira lan honen helburu. 


\subsection{Errealitatearen definizioa eta hedabideen ekarpena}

El poder se ejerce fudamentalmente construyendo significados en la mente humana mediante los procesos de comunicación (Castells 2010: 535).

Soziologiaren baieztapen arrunta eta zabalki onartua da gizartearen errealitatea giza ekintza eta eraikuntza -giza jarduera etengabea- dela, bai sorreran, bai sostenguan, bai aldaketan (Berger eta Luckmann, 1968). Hortaz, gizartea, aldi berean, errealitate objektiboa eta subjektiboa da: herritarren irudimenean (subjektibotasunean) bizi izanik, orobat, subjektibotasuna askoren artean partekatua den neurrian, gizabanakoaren pertzepzio pertsonalari objektibotasunez agertzen zaio. Gizartearen errealitatea mantentzeko, arrakalatzeko edo eraldatzeko, botere-harreman konplexuek eta dialektikoek parte hartzen dute.

Gizartearen eraikuntza-prozesu dialektiko horretan, komunikazioaren ekintza giltzarria denez gero, hedabideek zeregin berezia eta esanguratsua dute, bere funtzio nagusia komunikazioaren oinarrizko baldintzetako batekin lotua baitago, informazioa transmititzearekin, hain zuzen ere. Unescok argitaratutako "Kazetari-etikari buruzko Nazioarteko Kodea” deritzonak, bere lehenengo paragrafoan, kazetaritzaren oinarrizko funtzioa herriak benetako informazioa jasotzeko eskubidearekin lotzen du. Kazetaritza-lanbidearen Europako Kode Deontologikoak adierazten du bere 17. puntuan herritarren aipatutako eskubide hori nahitaezko baldintza dela bizitza demokratikoa izateko.

Baina informatzearen zeregina ez da ekintza neutrala eta soila, konplexua, baldintzatua eta baldintzatzailea baizik; neurri batean, fenomeno bat edo egoera bat komunikazio-guneetan islatzen dutenean, hedabideek errealitatea eraikitzen laguntzen dute (García, 2007: 90), hots, egoera jakin bat erreala bihurrarazten dute herritarren kontzientzian. Horrela, egunkari bat -oro har, hedabideak-, irismen handikoa eta irakurria den heinean, herritar arrunta kezkatzen duena jasotzeko bitartekoa ez ezik, herritarraren kezka eta interesa sorrarazteko eta moldatzeko tresna eraginkorra ere izan daiteke. Jakina, botere sozialek biziki estimatzen dute funtzio hori, David Edwards eta David Cromwell (2006) kazetarien saioak -Guardians of Power. The Myth of the Liberal Media- ondo asko erakusten duenez, Noam Chomsky-k (Chomsky - Ramonet, 1996: 7-8, 14) plazaratutako intuizioei jarraituz. Leku oro, bai tokian tokiko eremuak, bai mundua bere zabaltasunean, etengabeko gertaeraz josirik daude, zeinek gizabanakoaren eta gizarte jakin baten bizitza baldintzatzen duten, hortaz, aukera berriak sortzea zein bizitzaren amaiera ekartzea; hala ere, bizitza guztia bere sakoneran eta hedaduran ezin daiteke irudikatu paper-orri beti mugatuetan. Nahitaez, aukerak egin behar dira: zer albiste jasotzen den eta zer uzten, nola aurkezten den eta zeri ematen zaion garrantzia, non agertzen den eta noiz desagertzen, nork hitz egiten duen eta noiz (García, 2007: 89). Aldez edo moldez, albisteetan errealitatea bera aukeratua, moldatua, ebakia edo eraikia denez, hedabideak ez dira errealitatearen paisaia neutraltasunez eskaintzen duten leiho soilak, errealitatearen markak eta koloreak leihoaren kristalek ipintzen baitituzte sarri askotan.

Egia da hedabideen mundua eraldaketa sakon batean murgildurik dagoela, bide alternatiboak eta aukera berriak sortu baitira sare sozialetan, Internet-en, komunikazio-teknologia 
berrietan, eta abarretan ( García, 2007: 91; Castells, 2010: 87-92). Informazioaren prozesuan, kazetarien bitartekaritzari dagokionez, aldaketa teknologikoa dela-eta, XX. mendeko azken hamarkadetan bitartekaritza hori desagertzear zegoelako ustea zabaldu bazen ere, azken urteetako eboluzioak bestelako norabidea erakusten du. Internet-ek -iraultza teknologiko horren erakuslehioa- ez du kazetaritzaren desagerpena ekarri, lanbide horren eraldaketa baizik, informazioaren ekoizleak eta informazioaren kontsumitzaileak harreman-eredu berri batean kokatuz; azken urteetako ikerketak ondo asko erakusten duen bezala, harreman-eredu berrian, kazetaritzaren zereginak guztiz beharrezkoa izaten jarraitzen du (Cardoso, 2010: 217-228). Hori ulergarria da gorago esandakoagatik: errealitate soziala sozialki definitua izan behar da, eta definizio horrek aukeraketa bat eskatzen du beti. Aukeraketa beharrezkoa izanik, kazetaritzaren zeregina nahitaezkoa da. Hori dela-eta, badirau gorago aipatutako neutraltasunik ezaren arazoak, elite sozialek eta ekonomikoek hedabide handiak kontrolatzen baitituzte; hortaz, hedabide horiek oso boteretsu izaten jarraitzen dute, bai modu tradizionaleko komunikabideetan, bai gizarte-sare digital berrietan; azken batean, berrikuntzak berrikuntza, herritarren subjektibotasunean erreala zer den finkatzeko ahalmen nabaria kontrolatzen dute (Castells, 2010: 81-85; 535). Paradoxikoki, gaurko iraultza teknologikoaren ahalbideak goraipatzen badira ere, hedabide handien boterea modu demokratikoan eta juridikoan kontrolatzea edo arautzea gero eta zailagoa da (Padrós, 2010: 153).

Komunikabideetan, bitartekoak bitarteko, botere-jokoa dago tartean, eliteekin eta gizarte gehiengoaren irudiekin bat datozen ikuspegiak eta planteamenduak sostengatzen eta errepikatzen dira, eta gutxiengoen ikuspuntuak -are gehiago, gutxiengoen existentzia-ikusezin bihurtzen dira (Edward - Cromwell, 2006). Modu berezian, errealitate soziala eraikitzean, hedabideek ekarpen esanguratsua egiten dute "besteak" eta "gutarrak" zer eta nola diren definitzen dutenean (García - Uriarte, 2011). Oro har, "besteak” dira hurbilak ez direnak, giro batean arraroak edo arrotzak baitira; agian, besterik gabe, ezezagunak. Kategoria horretan hainbat kolektibo sartzen dira, besteak beste, gutxiengo erlijiosoak, hain zuzen ere. Talde horiek ikusezin edo ikusgarri izan daitezke gizartean komunikabideen jardueraren arabera. Ikusgarri bihurtzen dutenean, emaitza anbiguoa da: hedabideek betiko estereotipoak areagotzeko eta xelebrekeriak zabaltzeko funtzioa bete dezakete, edo, alderantzizko norabidean, talde erlijioso horiek hobeto balioesteko eta ezagutzeko, ekarpen esanguratsua egin dezakete. Ildo horretan, Montserrat Coll-ek -Kataluniako Generalitatean Gai Erlijiosoen Zuzendari Nagusi ohiak- azaltzen du bere helbururik garrantzitsuenetako bat erlijioari buruzko gaizki-ulertuak eta aurreiritziak gainditzea dela, eta helburu hori lortzeko, komunikabideen jarduera oso lagungarria izan daitekeela (Consell de l'Audiovisual de Catalunya, 2010: 9).

\subsection{Erlijioaren esanahi soziala}

Erlijioaren fenomenoa errealitate sozialaren partea da garai eta kultura guztietan (Beger, 1981), nahiz eta fenomeno horren esanahi eta balio soziala oso anitza eta aldakorra izan. Zenbait soziologok (Durkheim, 1982: 387; Mardones, 1994: 31) azpimarratu dute gizartearen ibilbidea eta aldaketak irudikatzeko, erlijioaren errealitatea -bere gorabeherak barne- 
oso esanguratsua dela; baieztapen horren lorratzean, nolabaiteko intuizio soziologikoak susmatzen du gizartearen sakoneko prozesuek, aldaketarik esanguratsuenek eta eraginkorrenek erlijioaren ibilbidearekin eta eraginarekin barne lotura erakusten dutela.

Gure artean, erlijioaren fenomenoak zenbait ezaugarri erakusten ditu, zeinak kontuan izan behar ditugun gure gaia ondo kokatzeko, herritarren inkontzientea markatzen baitute neurri handi batean.

a) Denbora gutxian, hots, belaunaldi bateko ibilbidean, sekulako aldaketa izan du erlijioaren lekuak eta esanahiak gure gizartean. Aldaketa hori azaltzea ez da erraza eta, zenbait teoria eta interpretazio egon arren (Sáez de la Fuente, 2002), egin gabe dago oraindik. Gizartearen zentro-gune izatetik, periferian kokatzera iragan da, sekularizazioaren prozesuaren esanahietako bati helduz. Periferia hori, behinik behin, hiru zentzutan erabil daiteke, hiru arlo ezberdinekin lotua den neurrian: instituzioekin, praktika sozialekin eta gizabanakoaren kontzientziarekin (Taylor, 2007: 2-4). Erlijioak gizartearen ibilbideaz eta bizitzaz zerbait esanguratsua adierazten badu, gure gizartea aldaketa sakon batek astindua izan dela azpimarratu genezake. Zentzu horretan, gure arteko herritar askorentzat erlijioa da gaurkotu ez den zerbait bitxi samarra, aurreko belaunaldiekin lotua zena (aitonen amonen kontua) baina gaur egun, modernitatearen testuinguruan, zentzurik gabekoa.

b) Aipatutako astindua gertatu baino lehenagoko egoera erlijiosoak monopolioaren antza zeukan, katolizismoaren monopolioa, alegia. Erlijioa periferiara joatea katolizismoaren ibilbidearekin lotua izan da, zeren eta, lehen beste erlijioren bat bazegoen ere, horien kopurua oso mugatua izateaz gain, guztiz marjinalak -sozialki ikusezinak- baitziren gizartean. Horren ondorioa zeharo esanguratsua izan da, erlijioa eta katolizismoa bateratuak joan baitira herritarren pentsamenduan; hortaz, erlijioa esatea eliza katolikoa aipatzea izan da -agian, gaur ere horrela da herritar askorentzat-. Gaurko egoera eta irudikapena ibilbide horren zorduna da, historia eta egoera horrekin lotua baita, nahiz eta katolizismoak zentro-gune hori modu nabarmenean galdu. Horrekin batera, beharbada, erlijioaren eta moralaren artean gertatu den txirikordatzea esanguratsua eta ondorio askokoa izan da. Tradizio katolikoak moral bat jarri du eta, neurri handi batean, ildo beretik joan dira biak ala biak; agian, erlijioaren erredukzio -beharbada, identifikazio- moralak, eragin sozial handikoa izatearekin batera, ez dio fabore handirik egin erlijioa modu zuzenean ulertzeari.

c) Gaur egungo giro sekularizatuan, erlijio-aukera kontu pribatua dela ulertzeko eta onartzeko ez dago oztoporik, gizartearen eta kulturaren aniztasuna gero eta handiago dela kontuan izanik. Gaiaren mataza katigatzen da erlijioa arlo publikoaren eremuan kokatzen denean, bi korapilo agertuz: erlijioari buruzko ezjakintasuna eta erlijioa arazotzat jotzea. Lehenengo korapiloari dagokionez, Eusko Jaurlaritzaren txosten argitaratu berri batean adierazten dena oso esanguratsua da:

"Aipatu behar dugun lehenengo kontua Euskal Herriko errealitate sozio-erlijiosoari buruz dagoen ezjakintasun orokorra da. Ezjakintasun horren barnean daude, bate- 
tik, errealitate berri samar honen presentzia sozialarekin lotutako gaiak, eta bestetik, herri-administrazioaren estamentuen aintzatespen formaletik ondorioztatzen diren beste alderdi batzuk" (Eusko Jaurlaritza 2015: 9).

Bigarren korapiloari helduz, erlijioaren gaiak, oro har, arazoaren irudia dakar imajinario kolektiboan, gizartean nola kokatzen den eta erlijioak zer ekarpen egin dezakeen ez baita batere argi ikusten; zentzu horretan, eta munduko beste gizarte askorekin konparatuz, erlijioaren fenomenoan aukera onak eta ekarpen positiboak eskain ditzakeen faktorea ikusi baino gehiago, arazoa atzemateko joera dago, gizartearen bizitza atezuan (mehatxuan, agian) jartzen duen neurrian (Berger et al., 2008).

\section{GUTXIENGO ERLIJIOSOAK ETA HEDABIDEAK}

Hedabideen portaera eta jarrera gutxiengo erlijiosoentzat ez dela garrantzi eta esanahi gabekoa guztiz ulergarria da. Egunkarietan, telebistan edo beste edozein foru publikotan, talde horiekin zuzen edo zeharka lotutako albisteek eta iruzkinek atentzioa ematen die gutxiengo erlijiosoen partaideei eta, hortaz, arreta berezia jartzen dute agerpen horien jarraipenean. Gure ikerketen testuinguruan, talde horien ordezkariekin eta kideekin izandako bileretan eta elkarrizketetan, gaia esanguratsua eta sentikorra dela ondo asko islatzen zen. Izandako harreman horietan, kezkak eta, batzuetan, kexak tartekatzen ziren behin eta berriro. Hedabideen portaera aztertzea ez zen gure hasierako gaia, ez zegoen gure galdera-sortan ere; hala eta guztiz, sarri askotan, hizpide saihetsezina gertatzen zen -beste gaien harira, artean edo azpian- partaideen egonezina erakusteko edo kritika mindua adierazteko. Hori dela-eta, gure ikerketen planean hedabideen gaia ez bazegoen ere, talde horien interesa zela ikusirik, gure lanaren agendan sartu eta azterketaren interesguneetako bat bihurtu zen.

Gaia ondo kokatzeko, gutxiengo erlijiosoetako partaideen zenbait ezaugarri kontuan izan behar ditugu. Lehenago aipatua izan denez, batetik, gure giro kulturala sekularizatua dela kontuan izanik eta, bestetik, katolizismoaren eta erlijioaren arteko identifikazioa dela medio, elkarte horietako partaideen fedea nekez izan daiteke soziologikoa, inguruko baldintza sozialak eta kulturalak kontra baitituzte; neurri handi batean, biografia bakoitzaren gorabeherak gorabehera, talde horietan partekatzen den fede-bizipena aukera pertsonalean oinarritua dago, inguruko giroaren laguntza gabe eraikia eta ikusezintasunean bizitzen ikasia. Zentzu horretan, aukera militanteari buruz mintzatzen ari gara, partaideek arrazoi pertsonal onak izan behar baitituzte bere fedearen aitortza egiteko eta plazaratzeko, baita bere horretan irauteko ere; gizartearen korrontea alde ez izanik, neketsua da eguneroko arraunketa.

Horrekin batera, pertsonarentzat guztiz esanguratsua den aukerari buruz mintzatzen ari gara, zein bizitzaren azaleko planoan kokatuta ez dagoen, erdigunean baizik. Garrantzitsua da konprenitzea fede erlijiosoa, benetako aukera pertsonala bada, gizabanakoaren identitate-erdigunean kokatzen dela; hortaz, fede erlijiosoa ez da identitatearen beste ezaugarri 
arrunt bat, periferikoa eta eragin handirik gabekoa pertsonaren izaeran, baizik eta fededunak bere burua deskribatzeko eta identifikatzeko, azken batean, ulertzeko, oso aukera esanguratsua. Fede-bizipen hori desagertzen bada, pertsonaren bizitza ez da berdin izango, aldaketa sakona gertatzen baita bere baitan, bere barneko bizipen sakonean, alegia.

Gehienetan, gutxiengo erlijiosoek gizartean parte hartzeko nahia eta borondatea dutenez gero -horrela adierazten dute sarri askotan-, gizartearekiko harremana bilatua eta esanguratsua da, nahiz eta zaila izan behin baino gehiagotan. Bere bizipena eta mezua ez da erraza partekatzea eta komunikatzea gizartearen aipatutako baldintzetan: giro sekularizatuak nekez ulertzen du zertan datzan erlijioaren bizipena eta sentiberatasuna; bestaldetik, hemengo kasuan, erlijioa eta katolizismoa berdintzeak zailtasunak gehitzen ditu, gutxiengo elkarte horiek leku sozialik gabe geratzen baitira. Hori dela-eta, gutxiengo sozial batek gizartean esanguratsua izateko, oztopo bereziak izaten baditu beti, gure giro kulturalean, gutxiengo erlijiosoen zailtasunak areagotu egiten dira.

Hori horrela, talde horiek gehien kezkatzen dituen gaietako bat gizartearekin ondo eta zuzen komunikatzea da. Komunikazio hori egin beharraz ez dute inolako zalantzarik; bidea eta aukera, berriz, ez ohi dago beharra bezain argi. Oro har, bi estrategia posible agertzen zaizkie, biak ala biak batera eman daitezkeenak, planteamendu ezberdinak izan arren; lehenengoa da berezko bideak antolatzea eta kudeatzea; bigarrena, ohiko hedabide arruntetan parte hartzea edo hedabide horien ekimena itxarotea.

Zalantzarik gabe, gizartearekin komunikatzeko, berezko bitarteak erabiltzea da aukera lehenetsia eta bide horretan saiatu dira. Batzuek (Eliza Adventistak, esaterako) bere irratia martxan jarri dute; dena den, ekimen hori ez da erraza, batez ere zaila da denboran mantentzea, zeren, dedikazioa eta borondatea ez ezik, gaitasun teknikoak eta profesionalak ere behar baitira, eta horiek ez daude beti eskura. Zenbaitetan, ahalegin hori egin arren eta martxan jartzea lortu arren, ibilbidearen une batean eten behar izan dute irratiaren proiektua, azken batean pertsona kalifikatu jakin baten edo batzuen lepoan sostengatzen baita, eta pertsona horiek falta izanez gero, zerbitzua ezin daiteke iraunkorra izan. Esaterako, hori gertatu zen Iglesia Cuerpo de Cristo delako taldearekin -arlo sozialeko bere lan-izenarekin, REMAR, hobeto ezagutua-; hainbat urtez irrati bat mantentzeko gai izan ziren elizaren partaideak, baina komunikazio-zerbitzu horretako arduraduna joan zenean, ez zuten inor aurkitu ekimen horri jarraipen emateko eta, ondorioz, eten egin behar izan zuten zerbitzu ondo asko estimatua.

Talde bakoitzak bere komunikazioa antolatzeko eta partekatzeko beste modu bat weborriak dira. Gehiago edo gutxiago gaurkoturik, elkarte askok -gaur egun 60 inguru- webgune bat prestatu dute, guztien begien bistako dagoen berezko komunikazioa, non elkarte bakoitzak barneko informazio esanguratsua eskaintzen duen. Dena den, webguneak gaurkotuta mantentzea ez da lan erraza, eta zeregin horretan ere talde baten esfortzuaren eta dedikazioaren beharra dago.

Berezko komunikabideak erabiltzeaz gain, ohiko hedabide ezagunen aukera dago: egunkariak, aldizkariak, irratia, telebista, etab. Jakina, ezin daiteke espero hedabideak elkarte txiki 
ezezagun horietan interesaturik egotea; gutxiengo erlijiosoek jakin badakite ikusezinak direla gizartean, neurri handi batean. Dena den, zenbaitetan gertatzen da hedabideen fokua gutxiengo horietan jartzen dela; orduan, gutxitan gertatu arren, hedabideek sekulako eragina dute iritzi publikoa moldatzean; ematen den informazioa desitxuratua edo aurreiritziz josia bada, ondorioak oso larriak izan daitezke gutxiengo elkarte horientzat, isolamendu sozialari gaitzespenaren arriskua eta zama eransten baitzaio. Alderantziz, informazioa ondo taxutua eta modu zehatzean eskainia bada, giroko zenbait aurreiritzi ahultzearekin batera, talde horien existentzia arazo bat dela pentsatzetik, aukera eta ekarpen positiboa izan daitekeela balioestera pasatu daiteke iritzi publikoa.

Gutxiengo erlijiosoak hedabideetan agertzeko moduari erreparatuz, oro har, bi era bereiztea komenigarria da: lehenik, elkarteak berak bere ikuspuntua ematea, gehienbat, modu zuzenean kontsultatua izanez; bigarrenik, hurrengo atalean garatuko duguna, taldeari buruzko albiste edo iruzkin bat argitaratzea, taldeko kideen ikuspuntua agertu gabe. Era orokorrak dira, eta horietako bakoitzean hainbat aldaera egon daitezke.

Lehenengo era, hots, taldeak bere iritzia eta ikuspuntua modu zuzenean eman dezakeenekoa, interesgarriena da gutxiengo horientzat, beraiek taxutzen baitituzte komunikazioaren edukia eta modua. Era horren barnean, aldi berean, hiru modu dira ohikoenak (beste batzuk posible izan arren, oro har, ez ohi dira erabiliak): informazio orokor batean taldearen aipuak agertzea, elkarrizketa bat argitaratzea eta, azkenik, taldeak bere programa edo espazioa kudeatzea.

a) Albiste jakin baten harira, are gehiago egoera problematikoa denean, inplikatutako gutxiengo erlijiosoari galdetzea eta bere aipuak jasotzea elkartearen ikuspuntua jasotzeko bidea ez ezik, aldezteko modua ere izan daiteke, zalantzarik ez. Hala ere modu arriskutsua ere izan daiteke, zeren eta aipuen esanahia bere testuingurutik aterata gaizki ulertua izan baitaiteke sarri askotan (López, 2002). Horretaz, islamiar komunitate bateko kidearen lekukotasuna:

(...) siempre ha venido algún periodista cuando ha habido algo, tanto en Eibar como en Bilbao; por ejemplo en la Fiesta del Cordero, (...) hemos salido en la televisión. De los periodistas hemos recibido un trato estupendo, aunque siempre hay que hacer notar que a veces tú quisiste decir algo y en la versión final te entendieron de otro modo y aparece distinto de lo que dijiste ${ }^{2}$.

b) Elkarrizketa, bere osotasunean eskainia denean, oso modu egokia izan daiteke taldearen ikuspuntu zuzena jasotzeko eta transmititzeko. Dena den, modu horretan ere zenbait muga eta kontuan izateko hainbat baldintza txirikordatzen dira. Gehienetan, hedabideek espazio (denbora) mugatuak dituztenez gero, edukiaren selekzioa erabaki behar da; nork erabakitzen du aukera hori? Elkarrizketatutako elkarte erlijiosoak gutxitan egiten du selekzio hori. Elkarrizketa egiteko testuingurua ere baldintzatua dago, normalean

${ }^{2}$ Beste gauzarik esan ezean, aipu guztiak gure ikerketetan egindako elkarrizketetatik aterata daude. 
suertatzen baita albistearen fokua izatea gertaera bereziren bat-behin baino gehiagotan desatsegina- jazo delako, eta, zalantzarik gabe, horrek kutsatzen ditu elkarrizketaren giroa eta edukia. Egoera horiek erosoak ez izan arren, elkartearen ikuspuntua eskaintzeko eta bere arrazoiak aldezteko aukera izaten dute.

Eliza eta elkarte erlijioso batzuek badute barneko antolamendu bat hedabideekiko harremanak kudeatzeko; Espainiako Jehovaren Lekukoek eta Iglesia Cuerpo de Cristo izeneko elkarteak badute arduradun bat prentsaren eskaera horiei erantzuteko eta lotura hori zaintzeko; zenbait kasutan, harreman-zerbitzu hori ministerio bat -zerbitzu instituzionala- da taldearen barneko antolamenduan, Iglesia Luz del Mundo izeneko kasuan, esaterako. Talde barneko zerbitzu edo antolamendu hori dagoenean, hedabideen ibilbideei eta albisteei jarraitzea errazten da, denboraren poderioz, eskarmentu handia bereganatzen baitute zeregin horren arduradunek. Antolamendu hori ez dagoenean, zailagoa da harremana mantentzea eta unean uneko errealitateari eta egoerari modu egokian erantzutea. Dena den, gutxiengo erlijiosoen iritzian, gutxitan dira deituak eta, oro har, baztertu samar sentitzen dira komunikazio publikoaren eremuan.

c) Batzuetan, gutxiengo talde horietako baten batek irratiaren edo telebistaren aldizkako espazio edo programa bat kudeatzeko aukera du. Prentsa idatzian ez da aukera hori suertatu eta, ziur aski, zaila izango da gertatzea, baina irratian eta telebistan azaldu zaie komunikatzeko bide hori. 90eko hamarkadan EITB komunikazio-enpresa publikoak EAEko Kontseilu Ebanjelikoari aukera eskaini zion asteroko programa bat prestatzeko eta igortzeko. Ebanjeliokoek ulertu zuten aukera eta erronka esanguratsua zela eta lanari gogoz heldu zioten. Kontseilu horretako kide batek aitortzen du aukera hori oso garrantzitsua izan zela eta bere lanaren agenda markatu zuela neurri handi batean, kalitatezko programa prestatuz jendearen interesa erakartzeko.

El siguiente hito probablemente fue el programa de televisión, uno de los que quizás más ha marcado y ha lastrado al Consejo. Cuando se consiguió tener el programa en la ETB, en la década de 1990, ahí hay un hito que marcó algo importante, el hecho que los evangélicos tuvieran acceso a un medio de comunicación público, que se pudieran presentar con libertad, cosa que prácticamente no había sido posible hasta entonces. Pero al mismo tiempo lastró la tarea del Consejo, porque nos absorbió mucho y nos hizo desatender otras cuestiones que eran también muy necesarias para nosotros. Ha sido el programa de EITB quien ha marcado el rumbo del CEPV, de modo que poco se puede decir de otros períodos de nuestra historia con posterioridad.

Dena den, saio horiek igortzeko ordua ikusleria eskasekoa kexaren zioa izan da (Eusko Jaurlaritza 2015: 11), eta, aldi berean, interesaren galera ekarri du; azken batean, baldintza horietan elkartearen komunikazioak errealitate sozialaren bazterreko kontu izaten jarraitzen. 


\section{GUTXIENGO ERLIJIOSOEN KRITIKA}

Gutxiengo erlijiosoek badute eskarmentua hedabideekin; harreman horrek, zalantzarik ez, elkarte horien interesa adierazten du; azken finean, komunikabideekiko harremanean gizartearekin komunikazio zuzenean jartzeko aukera agertzen baita. Aurreko paragrafoan agerian geratu denez, hedabideekiko harremana ez da soila eta era batekoa; gaur egungo testuinguruak hainbat aukera eskaintzen dituenez gero, harremana askotarikoa da eta, hortaz, elkarte erlijioso horien eskarmentua anitza. Dena den, puntu batean guztiak datoz bat: gaia oso esanguratsua izateaz gain, sentikorra eta arriskutsua ere bada.

Oro har, egoera eta komunikatzeko baldintzak lehen baino hobeak direla esatean kontsentsu zabala agertzen da; eskaintzen den informazioa gero eta begirune handiagokoa izanik, onerako pausoak eman direla onartzeko joera bat dago.

(Antes los periodistas) no se hacían tan responsables. Ahora se contrasta la noticia, pues alguien dice (algo sobre) los testigos de Jehová, nos llaman y dicen va a salir esta noticia, me gustaría conocer vuestro punto de vista. Entonces, generalmente en el programa, sale lo que opina fulanito y lo que opinan los testigos; así es el ciudadano, el televidente o el lector es el que saca su conclusión.

Hedabideekiko harremanetan emandako aurrerapausoak aurrerapauso, harreman horien alde positiboak ez dira gehien azpimarratzen direnak, ezta hurrik eman ere; aitzitik, ikuspuntu kritikoak dira ugarienak. Oro har, kexa horiek lau ataletan sailkatu ditugu, ondoren aletzen ditugunetan.

\subsection{Ikusezintasuna}

Gehienetan, hedabideek ikusezin bihurtzen dituzte gutxiengo erlijiosoak, oso gauza bitxia gertatu ezean, ez baitira inoiz albiste. Filadelfiako Elizaren kide batek kexuz nabarmentzen $\mathrm{du}$, elizaren ospakizun esanguratsu batean kirol pabiloi handi bat mukuru betetzeko aurreikuspena dutenez gero, prentsari abisua ematen diote; hala ere, ez da kazetari bat ere hurbiltzen gertakari horretara.

Ikusezintasunaren beste zantzu bat programazioaren ordutegia dugu. Telebistan, ebanjelikoek programa bat kudeatu ahal izatea hedabideetan aniztasun erlijiosoa onartzeko eta normalizatzeko pauso positiboa dela aipatu badugu ere, eskaintza horrek badu bere alde negatiboa, telebista-saioaren ordutegia, hain zuzen ere; igandeetan, goizeko 8:30etan ematen denez gero, basamortuko ahotsa bezala, oso ikusleri eskasera ailegatzen da komunikatzeko esfortzu hori.

Batez ere ebanjelikoek kritikatzen dute munduan gertatzen diren ospakizun ebanjeliko unibertsalki esanguratsuak (errege ebanjeliko baten ezkontza, esaterako) sistematikoki isilaraziak direla hemengo komunikabideetan. Zentzu horretan, espiritualtasunari edo konpromiso sozialari lotuta, munduan zehar esanahi handiko pertsonaia ebanjelikoei garrantzia kentzen zaielako susmoa adierazten dute eliza horien ordezkariek. 
Si muere un misionero protestante en África, se dice que ha muerto un misionero cristiano, o un cooperante. Pero si es un sacerdote católico, o una monja, entonces se la eleva a los altares como a un mártir.

Kazetariarentzat misiolaria eliza protestante batekoa izatea esanguratsua ez denez, hildakoaren ezaugarria modurik orokorrenean ematen da, kristaua edo laguntzailea zela adieraziz. Eliza ebanjelikoko kideentzat, berriz, gure gizartean gutxiengo ikusezineko partaidea izanik, misiolaria protestantea izatea oso ezaugarri esanguratsua da, baina ezabatua geratzen da, ikusezintasuna handituz. Ildo beretik, Pedro Tarquis-ek -hainbat urtez FEDEREN-eko komunikabideen arduraduna- salatzen du "Eliza" hitzaren erabilera, normalean singularrez eta nolabait adieraziz eliza bat baino ez dagoela, eta hori Eliza katolikoa dela (Tarquis, 2009).

\subsection{Alde negatiboak azpimarratzeko joera}

Albisteak ematean, aurkezpenak, deskribapenak eta azalpenak kutsu negatiboarekin batera doaz sarri askotan, deserosotasuna edo mehatxua adierazten duen zerbaitekin lotzen baitira talde horiek. Eliza Bautista bateko partaideak ohartarazten du hedabideek portaera bitxiko eta harrigarriko talde erlijioso txikiei atentzio gehiago ematen dietela ohiko elizen bizitzari eta ibilbideari baino:

Diría que a veces hay una actitud maliciosa. He visto cosas que están sacadas de su contexto. A veces hay congregaciones con las que no puedo estar de acuerdo con su forma, con su manera de actuar; pero (los medios de comunicación) siempre van a eso, a lo extravagante; no sé, la cuestión es meter miedo al pueblo.

Horrekin batera, gutxiengo erlijiosoekin lotuta arazoren bat suertatzean, komunikabideetan agertzeko probabilitatea handitzen dela nabarmentzen dute, inkontzienteki arazoaren eta talde horien arteko lotura egiteko joera areagotuz:

Venden mucho más los problemas, venden mucho más el tumulto, muchas veces se cogen cosas de personas que han venido de afuera, que si telepredicadores, que si se aprovechan de la gente, que si no sé qué, y cogen imágenes en cámaras ocultas, cosas que no ayudan en nada a la integración de las minorías religiosas sino todo lo contrario.

Ildo berean, testuingurutik ateratako mezu gaizki ulertuak gertatzean, gehienetan alde negatiboa azpimarratua geratzen da. Eskarmentu hori azaltzen da elkarrizketatu askoren lekukotasunean, hedabideekiko mesfidantza hedatuz. Hori da, hain zuzen ere, Gipuzkoako islamiar emakume baten adierazpenean islatzen dena:

Pero la relación directa con ellos (los medios de comunicación social) ha sido buena, excepto una ocasión en que vino J. S., de La Cuatro, y nos hizo un reportaje que para mí fue terrible, desde mi opinión como musulmana. Nos llamó "Los legionarios de Alá”, anda tú a saber qué es eso, metió un término católico en el Islam. ¡"Los legionarios de Alá”!, ¡con la fácil que es decir “musulmanes”! Buscó un nombre raro, para que sonara más misterioso, estrategias de los medios de comunicación supongo. Vino a Bilbao, entró en la mezquita, hizo entrevistas. Personas así, que vienen con ese plan de reportaje, yo no las dejaría entrar, no les daría mi tiempo. Si tú vienes con humil- 
dad y respeto, entonces te doy mi tiempo, pero si vienes con un plan y muestras lo que te da la gana... Hasta la música daba miedo, parecía la música de "Scream”, y no de un reportaje, y sombras y cámaras lentas, como si los musulmanes fueran alienígenas y no personas que sienten, que tienen necesidades, que lloran, que sonríen y les brillan los ojos también.

Kasu horretan hitz eta sinbolo anbiguoak apropos erabiltzen dira. Albistearen fokua ez da pertsona ezberdinarengana hurbiltzea eta ezagutzea; aitzitik, bitxia eta arraroa izan daitekeena da bilatua eta nabarmendua, harridurarekin eta beldurrarekin jokatuz.

\subsection{Aurreiritziak}

Brigitte Vasallok, kultur arteko bitartekariak, ondo asko islatzen du aurreiritziak airean eta giro kulturalean daudela, GARA egunkariak egin zion elkarrizketa batean²:

Haien (emakume musulmanen) egoeraren gainean galdetu baino, gure begiradari so egin eta "emakume musulman" terminoarekin zer ulertzen dugun itaundu beharko genioke gure buruari. Izan ere, estereotipoen eraikuntzatik uler daitekeen kategoria zabalegia da. "Emakume musulmana" diogunean, Malaysiako abokatu lesbiana baten gainean pentsatzen ari gara? Edo New Yorkera lanera joandako emakume txinatar edo Parisko transexual batekin gogoratzen gara? Seguru ezetz. Gure begietara emakume musulmanaren estereotipoa betetzen duten horiek etortzen zaizkigu burura: atzerritarra, beltzarana, beloa daramana, ezkondua, heterosexuala eta otzana. Ñabardurarik gabeko emakume musulmanik ez da existitzen. Ardatz oso bestelakoengandik gurutzatuta gaude guztiak: adina, arraza, klase soziala, orientazio sexuala, testuinguru soziala, genero identitatea... Are gehiago, “emakume musulmantzat” jotzen dugun estereotipoa arrazan errotuta dagoela esatera ausartuko nintzateke, izan ere, termino horrek kristauak ala ateoak diren emakume arabiarrak ere jasotzen dituelakoan nago.

Informazioarekin batera, aurreiritziak tartekatzen dira, zeinak, inkontziente kolektiboan egonik, kazetariek partekatzen dituzten neurri handi batean eta hedabideen praktikak indartu eta areagotu egiten dituen. Aurreiritzi horiek ikusezintasunaren eta manipulazioaren praktikaren azpian daude sarri askotan.

Aurreiritziak sortzean eta hedatzean bi faktore txirikordatzen dira, iturri ezberdinekoak izan arren, elkar indartzen dutenak: erlijioa eta gutxiengo izatea. Aurrean ohartarazi dugu kultura sekularizatuan erlijioaren presentzia eta esanahia gaizki ulertuak izateko joera dagoela (Vidal, 2005: 40); erraztasun handiz sentimendu hutsarekin, iraganarekin edo manipulazioarekin lotzen da modu espontaneoan. Bestaldetik, gutxiengoak ezezagunak izanik neurri handi batean, ohikoa denetik eta ohitura partekatuenetatik zein onartuenetatik aldentzen direnez, mesfidantza-iturria izan daitezke, NIMBY ${ }^{4}$ efektua sorraraziz (Eusko Jaurlaritza 2015: 11; 18). Ezaugarri bi horiek bateratzen dira gutxiengo erlijiosoetan, hain zuzen

${ }^{3}$ Gara 14-11-12; eskuragarri dago: http://www.naiz.eus/eu/hemeroteca/gaur8/editions/gaur8_2014-11-22-06-00/ hemeroteca_articles/agintaria-gero-eta-kutreagoa-izan-kanpaina-are-eta-faltsuago-eta-zalapartatsuagoa-da. ${ }^{4}$ Not in my back yard. 
ere; horixe bera da eliza ebanjeliko baten artzainak iruzkintzen duena: "la sospecha de la gente, el desconocimiento de la gente hace que muchas veces se nos vea como grupos raros o sectarios”. Hori horrela, aurreiritziek erraztasunez eta naturaltasun osoz lotzen ditu talde horiek fanatismoarekin, modernitatearen kontra izatearekin, zientzia ez onartzearekin, intolerantziarekin, eta abarrekin. Irudi horrekin, bi jarrera dira ohikoenak: barre gaitzesgarria egitea edo arrisku beldurgarria ikustea.

Batzuetan, mesfidantzarekin eta beldurrarekin lotuta dagoen hiztegia erabiltzen dela salatzen da egindako zenbait elkarrizketatan; batez ere "sekta" hitzaren erabilerak irizpiderik eta bereizpenik gabe min handia egiten die elkarte erlijioso horiei.

\subsection{Kazetari adituen falta}

Zaila da erlijio-gaietan kazetari adituak aurkitzea (Aierbe, 2008: 115). Gutxiengo erlijiosoen testuinguruan eta esanahietan kazetari ondo formatuak ez dira asko eta hori informazioan nabaritzen da. Puntu honetan talde horien zenbait kritika bateratzen dira. Hiztegiaren doitasun falta kexa hedatua da, batez ere ebanjelikoen artean; modu orokortuan hedabideek eliza ebanjelikoei erreferentzia egitean, ebanjelista deitzen diete; bestaldetik, kontuan izan behar dugu islama kristautasuna baino ezezagunagoa dela, hortaz, sarri askotan erabiltzen den hiztegia eta informazioa ez da oso doia. Beste batzuetan, elkarte baten ezaugarria orokortu egiten da eta eliza edo tradizio bateko guztien ezaugarritzat hartzen da. Ildo horretatik, tradizio erlijio jakin bateko familia ezberdinak ez dira ondo identifikatzen eta nahastu egiten dira. Hori dela-eta, gutxiengo erlijiosoetako partaideek sentitzen dute hedabideek ematen dien tratamenduari seriotasuna eta doitasuna falta zaiola.

\section{HEDABIDEEI BEGIRA}

Aurreko paragrafoan gutxiengo erlijiosoen ikuspuntua jaso dugu. Beste leku batean erakutsi genuen hemengo egunkarietan gutxiengo erlijiosoei buruzko informazioarekin kutsu negatiboa lotzeko joera bat zegoela (García eta Uriarte, 2011), azterketa hartan "sekta” hitzaren erabilera oso nabarmena eta diskriminatzailea zela ohartaraziz. Oraingo honetan, azken bost urteetako hemengo prentsan agertu denari begiratuz, elkarte erlijiosoen kexek oinarririk ote duten jorratzen dugu, bertako prentsa idatzi irakurriena (irismen handienekoa) harturik: Noticias de Gipuzkoa, El Diario Vasco, El Correo, Gara, Deia, Berria. Oro har, gure atentzioa jartzen dugu talde horiekin lotzen diren balioespen negatiboetan eta nolabaiteko arrisku-kutsua antzematen diren albisteetan. Horrez gain, hiztegi desegokia edo gaiari buruzko ezagutza falta denean ere kontuan izaten dugu.

Aurreko hamarkadara arte, gutxiengo erlijiosoekin lotuta maiz agertzen ziren zenbait hitz iraingarri desagertu dira edo oso gutxitan agertzen direla ohartu gara. Testuinguru horretan, esangura berezia du "sekta" hitzaren erabilerak, zein gaur egun nazioarteko zenbait gatazka erlijiosoren testuinguruan agertzen den, ia-ia inoiz ez, ordea, hemengo gutxiengo erlijiosoei erreferentzia egiteko. Gogoratu behar dugu orain dela zortzi hamar urte pole- 
mika sutsua izan zela kontzeptu horren inguruan, hainbat elkarte erlijiosori etiketa hori jarri zitzaiela garaiko zenbait hedabidetan. Hitz hori ez erabiltzean, neurri batean gutxiengo erlijiosoekiko erreferentzia diskriminatzailea eta salagarria desagertu da, "sekta” hitza ordezkatzeko beste termino negatibo bat agertu gabe. Zalantzarik gabe, hori aurrerapauso bat izan da aniztasun erlijiosoaren tratamendu publikoan.

Islamarekin lotuta badago hitz bat gero eta gehiago erabiltzen dena eta zentzu erabat negatiboa hartu duena: "yihad” eta bere eratorriak. Bere jatorrian hitzak ez du zentzu mehatxagarria eta nahitaez indarkeriarekin lotua (Flaquer, 2002; Bramón, 2007)5, baina gaurko prentsan guda-zentzua hartzen du, eta sarri askotan terrorismoaren presentzia eta ekintza, batzuetan agerian, beste batzuetan ezkutuan; berarekin lotu ohi dira ekintza basatiak eta giza eskubideen kontra egindako hilketak eta bortxakeriak. Zenbait albistetan, hemengo islamiar kultu-zentroren bat nahasia izan da yihadismoarekin, bertako partaideren bat edo partaide ohiren bat Ekialde Erdian gertatzen ari den gerretako batean engaiatua izateagatik.

Badago hirugarren hitz bat, zentzu gaitzesgarria ez izan arren, txarto erabili ohi dena: ebanjelista. Esaterako:

... estos grupos llevan décadas en la capital alavesa. Son los mormones, algunas familias evangelistas, musulmanes y Testigos de Jehová. Otros, sin embargo, han nacido en el último lustro... rusos, rumanos y georgianos (El Correo 10-07-16).

La presencia de religiones foráneas... presencia, en función de sus centros, la segunda religión mayoritaria la representan los evangelistas, los cuales cuenta con 27 centros en prácticamente todos los distritos de la capital... (Deia 12-08-04).

Gehienetan, “evangelista” (ebanjelari) hitza jartzean, eliza ebanjelikoak izendatu nahi dituzte, oro har mundu protestante konplexua; baina erabilera hori ez da batere egokia, ebanjelariak ebanjelioen idazleak baitira, eta soilik talde batzuek hartu dute auto-izendatzeko modu bitxi hori.

Hiztegiaz gain, albistearen testuingurua ere esanguratsua da gure azterketan. Sarri askotan, gutxiengo erlijiosoei buruzko albisteak gatazka baten testuinguruan plazaratzen dira. Azken urte hauetan, batez ere Bilbon, kultu-zentroen inguruan polemika latza azaldu da, hainbat aldiz, polemika horrekin lotuta elkarte erlijioso horiek agertuz. Zenbait islamiar kultu-zentrok arazoak izan dituzte, bai mantentzeko, bai zabaltzeko, alde batetik, udalaren baimenak lortzeko zailtasunengatik, eta, bestetik, auzoen presioarengatik. Bilboko udalak jarri nahi izan duen kultu-zentroei buruzko legearen kontra errekurtsoa aurkeztu da eta prozesu horren harira hainbat albiste agertu dira egunkarietan, oro har, balioespenak baino informatiboak izan direnak. Polemika horretan gutxiengo erlijiosoen eskubideen de-

\footnotetext{
${ }^{5}$ Termino horretaz, Joan Vernet Ginés-ek (Barcelona, 1923) -arabiar gaiez aditua, Universitat de Barcelona (UB) ko katedratiko emeritua eta Koran testuaren itzultzailea- honela dio: "La guerra santa no existe. Yo he traducido dos veces el Corán y allí aparece la palabra yihad, que significa esfuerzo. Yo mismo en mis ediciones puse encursiva titulillos al texto coránico. En algún caso puse guerra santa, algo de lo que me arrepentiré toda mi vida. El problema es de transmisión y de interpretación, según las diferentes escuelas.» El País (2007/04/24).
} 
fentsa jokatzen da eta, neurri batean, horrela agertu da prentsan; hala ere, inkontziente kolektiboan eta irudi publikoan, talde erlijioso horiek gatazkarekin eta arazoekin lotzeko arriskua dago. Hortaz, modu inkontzientean, talde islamiarrak problematikoak direlako irudia zabaldu daiteke adi ez dauden biztanleen artean. Horren lorratzean, gatazka baino gehiago eta harago, elkarte horiek arrisku sozialarekin lotuak izan dira albisteetan, gehienbat islama. Bi adibide jarriko ditugu baieztapen hori ilustratzeko.

Lehenengoan, Gara egunkaritik hartua, honela agertzen zaio irakurleari lerro-burua: "Iglesia en declive, temor al islam en auge” (Gara 15-02-18). Horrela jarrita, irakurleak jasotzen duen mezua islama mehatxu bat dela eta mehatxu horrekin lotuta, nolabait, elizaren gainbehera azaltzen dela; hortaz, egoera sozio-erlijiosoa gaizki ulertua izateko bidea ematen du albisteak. Azpian agertzen den testuak ez du mezu hori transmititzen, ezta hurrik eman ere; elizaren gainbehera sekularizazioaren prozesuari lotuta azaltzen da eta islamaren hazkundeak mendebaldean immigrazioaren mugimenduan du bere azalpena; gainera, artikuluaren azken partean azaltzen zaigu islamaren presentziari buruz dagoen pertzepzio publikoa oso hanpatuta dagoela, Frantzian hautematen baita biztanleriaren herena islamiarra dela, hamarren batera ailegatzen ez denean. Beraz, artikuluan azaltzen dena, iritzi-idazkia izanik, eztabaidagarria da, baina orekatua eta defendagarria; hala ere, ez dator inola ere bat lerro-buruarekin, zein nahiko alarmista den.

Udaberriko igande batean, El Correo egunkariak (15-04-19) bere portadaren erdia hurrengo albistearekin betetzen du, letra larriz eta handiz: "Una mezquita de Barakaldo en el ojo del huracán”. Letra txikiagoz, eta azalpen gisa, ondorengoa: “Attawhid, reducto del salafismo en Euskadi, es considerada por la policía como una de las 'más radicales' de España”. Lerro-buru hori eta azalpena argazki baten barnean kokatzen dira, non agertzen den meskitaren izena eta pertsona baten irudia gerrikotik beherakoa (ematen du gizonezko bat dela islamiar estiloko janzkerarekin). Barneko partean, bi orri eskaintzen zaizkio albisteari, azalpen-artikulu batekin eta meskitako partaide bati egindako elkarrizketarekin. Informazioaren artean azaltzen zaigu zer den salafismoa, zenbait datu eskaintzen zaizkigularik6; deskribatutako egoeren artean, hurrengoa: Sirian hildako soldadu gazte bat (Redouah Bensbih) meskitan horretara joan ohi zen-eta, poliziak meskita zelatatzen du. Elkarrizketatuak ezeztatzen du indarkeriarekin edozein lotura, meskitan egiten dena eta islamaren zenbait ohitura eta erritu azalduz. Informazioaren edukiari dagozkionez, ez da ezer berririk eskaintzen, eta arriskuaren zioa nahiko erlatiboa da, argitaratutako datuei begira, behinik behin. Dena den, portadako lerro-buruak beste norabide batean jartzen du irakurlearen atentzioa: meskita arriskutsua da, mehatxu nabaria herritarrentzat.

Charlie Hedbo aldizkariaren kontrako atentatuaren ostean, hainbat albiste, informazio eta iruzkin agertu dira prentsan, arriskuaren mezu hori areagotu delako irudia emanez. Estilo eta joera hori ez da berria; aitzitik, azken hamarkadetan, zenbait adituk islamofobiaren fe-

${ }^{6}$ Antzeko informazioa (edukiari dagokionez) eta tratamendua (luzera eta estiloa) ekainaren 30ean agertzen da, egunkari berberean. 
nomeno gaitzesgarriari atentzioa jartzea eskatu dute (Bolado, 2004).

Dena den, orain arteko esandakoa errealitatearen alde bat da, eta horretan geratuko bagina, ez litzateke zuzena izango. Gutxiengo erlijiosoekin lotuta, albiste deskribatzaile eta informatzaile neutroak eta aurkezpen positiboak asko dira azken urte hauetan; aniztasun erlijiosoaren inguruan, gero eta albiste gehiago azaldu dira, horietako gehienak informazio neutrala eskainiz eta baten batzuk balioespen positiboak eginez.

Horrez gain, gertaera puntualekin eta desatseginekin lotuta ez dauden zenbait erreportaje interesgarri aurki ditzakegu. Esaterako, El Correo egunkarian (15-02-25), Espainiako sufismoari buruzko txosten erakargarria bezain ilustragarria agertzen da. Erreportaje-genero horrekin lotuta, konbertsioen historia biografikoren bat azaldu da azken urte hauetan, islamiar bihurtu direnenak batez ere. Gara eta Berria egunkariek zenbait erreportaje eta gogoeta eskaini dituzte islamiar zapiaren inguruan, baita gaurko islamaren egoeraren inguruan.

\section{AZKEN GOGOETAK}

Aniztasun erlijiosoa gure artean dela-eta, zenbait puntu izan ditugu aztergai: gutxiengo erlijiosoen ahalegin komunikatiboa, gai horretaz hedabideen (gehienbat hedabide idatzien) portaera, gutxiengo erlijiosoen kritika eta, azkenik, kritika horren oinarria hemengo zenbait komunikabide idatzi arakatuz. Hori guztia, aldaketa sakonean murgilduta dagoen kulturan, non erlijioa fenomeno aldakorra den eta hedabideen eraldaketa eta eragina oso nabarmena. Argi dago ezin dugula gure gizartearen argazki finkorik eta mugiezinik egin. Gure testuinguru kulturalean, biziaren oinarrizko erreferentziak, balio orientatzaileak, ohitura ziurtatzaileak eta sinesmen lasaigarriak zirimola batean baleude bezala, bisutsaren erdian kokatuta gaude, nahitaez garai aldakorretan murgildurik bizitzera behartuta: gauza handirik finkatu ezin daitekeen garaietan bizitzea egokitu zaigu. Hori aukeran ez izanez gero, gure biziaren baldintzatzat onartu behar dugu. Ataka horretan, mendebaldeko gizarte sekularizatuetan erlijioaren esanahia eta lekua zein izango den ikusteko dago oraindik, eta hainbat hipotesi plazaratuak izan badira ere, azken urteetako eskarmentuak ondo asko erakusten digu errealitateak harritzeko gaitasun bitxia eta berezia ohi duela.

Azken hamarkadetako ibilbideari so eginez, ez du ematen erlijioaren presentzia desagertzera doanik (noizbaiteko tesi ezagunaren eta onartuaren kontra), bai, ordea, erlijioaren presentziaren forma, hots, nola bizitzen den eta nola kokatzen den gizartean, zer nolako ekarpenak egiten dituen, nola komunikatzen den, etab. Forma-aldaketa sakon bat da tradizio erlijioso baten monopolioa arrakalatzea eta, horren ordez, aniztasunaren zantzu esanguratsuak eta egonkorrak azaltzea, hori guztia eboluzio-prozesu sakonean eta bizkorrean murgilduta. Testuinguru horretan, aniztasuna gero eta normaltasun handiagoz bizitzeko eta normaltasun horren ekarpenik onenak aprobetxatzeko, plaza publikoaren oihalean zer den ikusgarri eta zer den ikusezin atzematea azterketa oso esanguratsua ez ezik, beharrezkoa ere bada. Hori guztia hedabideen zereginarekin eta politikarekin lotuta 
egonik, bi korapilo agertzen zaizkigu, bakoitzak bere erronkekin: erlijioaren fenomenoa zuzen ulertzea eta aniztasun erlijiosoaren presentzia onartzea eta erakustea. Lehenengo korapiloari dagokionez, aldi berean, bi erronka zirriborratzen dira. Lehenik, erlijioaren alde positiboak identifikatzea eta partekatzea, hots, sozialki ulertzea ez gaudela arazo baten aurrean, ezta modernitateaz eta postmodernitateaz kanpo dagoen fosil mehatxagarri baten aurrean ere; aitzitik, gaurko gizartean eta bere etorkizunaren eraikuntzan erakarpen interesgarria egin dezakeen elementu sozial baten aurrean. Bigarrenik, erlijioa tradizio katolikoarekin ez identifikatzea aipatu dugu, zeina gure gizartean oso ohikoa den. Bigarren korapiloa honela formulatu genezake: erlijioa errealitate anitza eta askotarikoa dela onartzea ez ezik, aniztasun eta askotarikotasun horren onurak balioestea ere. Jakina, bigarren korapilo horrek bere erronka dakar, eta ez txikia, aniztasun eta askotarikotasun horiek kudeatu behar baitira modu publikoan. Testuinguru horretan, Kataluniako Generalitatean Gai Erlijiosoen Zuzendaria zen Montserrat Coll-en proposamena oso zentzuduna iruditzen zaigu (Consell de l'Audovisual de Catalunya, 2010: 10) komunikabide publikoetan islatu behar dela aniztasun eta askotarikotasun erlijiosoa defenditzen duenean, informazio profesionala egokia eta doia eskainiz, hots, xelebrekerietan eta istoriotxoetan geratu gabe. Proposamen horri heltzeko, kazetariek gaiaz formazio espezifikoa jaso beharko luketenez gero, erlijioaren egitatea, aniztasuna eta askotarikotasuna Unibertsitateko Kazetarien formazio programan sartzea guztiz komenigarria izango litzateke (agian, erronken zerrendari eranstekoa).

Zalantzarik gabe, komunikazio sozialean gutxiengo erlijiosoek oso interes handia dutenez, aipatutako erronkak mintzagai eta kezka dira talde horietan, informazioaren kontraesanak ondo asko erakutsiz. Hortaz, aukeran, bere komunikabideak izan nahiko lituzkete, hots, gizartean bere mezua modu zuzenean azaldu nahiko lukete, bitartekaririk gabe; helburu hori betetzen saiatzen badira ere, baliabideen eskasiak ez die aukera handirik ematen gehienetan.

Hori horrela, oro har, gutxiengo erlijiosoei buruzko informazioa ohiko hedabideen bitartez zabaltzen da gizartean; hortaz, hedabide horiekiko harremanak nahitaezkoak dira, beti errazak ez badira ere, lan honetan erakutsi dugunez. Gehienbat, gutxiengo erlijiosoak kritikoak dira hedabideen portaerarekin, besteak beste, gaizki-ulertuak, kontzeptu txarto erabiliak, sentsazionalismoa, ikusezintasuna, etab. direla medio. Kritikak kritika, azken urte hauetan aztertutako hedabideen eboluzioak baikortasunerako bidea ematen digu. Hedabide horiek, oro har, gaia orekaz eta modu positiboz ukitzeko joera erakusten dute, gero eta gehiago. Besteak beste, azpimarratzekoa da hiztegi iraingarria ahuldu eta, neurri handi batean, baztertu dela.

Azkenik, esan dezagun ezin daitekeela gure gaian agertzen den arazoa ulertu gure giro kulturalean dagoen komunikazio-arazoari erreparatu gabe. Komunikazioan, zenbait kritika badira ere, akats horiek guztiak ezin dizkiogu hedabideen erantzukizunari egotzi; giro kulturalean ere bada zerbait egiteko. Hori kontuan izanik, hedabideen funtzio pedagogikoa berriro azpimarratzen dugu, zeren eta, giro kultural hori sortu ez badute ere, eragin handia izan baitezakete giro horren iraupenean edo aldaketan. Soziologikoki desinteresak edo 
mehatxuaren pertzepzioak jendearen jarrera eta pertzepzioa baldintzatu arren, desinteresa gainditzeko eta beldurra desegiteko, komunikabideen ekarpena oso esanguratsua izan daiteke, erreportaje eta albiste interesgarriak eta orekatuak eskainiz. Ziur aski, ekonomiari dagokionez, beldurra eta morboa errentagarriak izan daitezke; alabaina, oso kaltegarriak ere badira gizarte osasuntsua eraikitzeko.

\section{BIBLIOGRAFIA}

Aierbe, P. (2008). Herramientas para trabajar las buenas prácticas informativas. In Martínez, M., Inmigración, discurso y medios de comunicación (113-125 or.). Alicante: Instituto Alicantino de Cultura Juan Gil-Albert.

Bañon Hernández, A. M. (1996). Racismo, discurso periodístico y didáctica de la lengua. Almería: Almería Universidad.

Berger, P. Luckmann, Th. (1968). La construcción social de la realidad. Buenos Aires: Amorrortu.

Berger, P. (1981). El dosel sagrado. Para una teoría sociológica de la religión. Bartzelona: Paidós.

Berger, P. Davie, Gr. Fokas, E. (2008). Religious America, Secular Europe? A theme and Variations. Burlington: Ashgate.

Bolado, A. C. (2005). Islam, islamismo, islamofobia. Barcelona: Foro Ignacio Ellacuría.

Bramón, D. (2007). Yihad' y perversión del lenguaje. In El periódico, 2007/01/23, eskuragarri dago: http://www.caffereggio.net/2007/01/23/yihad-y-perversion-del-lenguaje-dolors-bramon-el/

Cardoso, G. (2010). Los medios de comunicación en la Sociedad en Red. Barcelona: UOC.

Casanova, J. (2000). Religiones públicas en el mundo moderno. Madrid: PPC.

Castell, M. (2010). Comunicación y poder. Madrid: Alianza Editorial.

Chomsky, N. Ramonet, I. (1996). Cómo nos venden la moto. Barcelona: Icaria.

Conill J. Gozálvez V. Camps V. (Arg.) (2004). Etica de los medios: Una apuesta por la ciudadanía audiovisual, Barcelona: Gedisa.

Consell de l'Audiovisual de Catalunya (2010). Medios de comunicación y pluralismo religioso. Barcelona.

Diezhandino, M. P. Marinas, J. M., Watt, N. (Arg.) (2002). Etica de la comunicación: Problemas y recursos. Madrid: Edipo. 
Dijk T. A. van (Arg.) (2002). Discurso e inmigración: Propuestas para el análisis de un debate social. Murcia: Universidad de Murcia.

-, (2003). Racismo y discurso de las élites. Bartzelona: Gedisa.

Durkheim, E. (1982). Las formas elementales de la vida religiosa. Madril: Akla.

Edward, D. Cromwell, D. (2006), Guardians of Power. The Myth of the Liberal Media. Londres: Pluto Press.

Eusko Jaurlaritza (2015). Euskadiko erlijio aniztasunaren kudeaketa positiboari buruzko txostena. Vitoria-Gasteiz: Eusko Jaurlaritza.

Flaquer, J. (2002), Diez preguntas para entender el islam. Bartzelona: CiJ. Eskuragarri dago: https://www.cristianismeijusticia.net/es/10-preguntas-para-entender-el-islam.

García, D. Uriarte, L. (2011). Las minorías religiosas y los medios de comunicación en la CAPV. In Ruiz Vieytez, E. J. (Arg.), La diversidad religiosa en el País Vasco. Nuevos retos sociales y culturales para las políticas públicas. Bilbo: Deustuko Unibertsitatea.

García, J. A. (2007). Periodismo e información. Una aproximación crítica. In Méndiz, A. Cristófol, C.. Falsedad y comunicación. Publicidad engañosa, Información falsa, Imagen manipulada. Málaga: Universidad de Málaga.

Habermas, J. (2008). El resurgimiento de la religión, ¿un reto para la autocomprensión de la modernidad? Diánoia, Liburuki LIII, zbk 60 (2008), 3-20 or.

López Pan, F. (2002). De la conversasión al texto. Acerca del pacto de lectura de la entrevista de prensa. In Diezhandino, Pilar - Marinas, J. M.l - Watt, N. (Arg.) Ética de la comunicación (129-137 or.). Madril: Edipo.

Mardones, J. M. (1994). Para comprender las nuevas formas de la religión. La reconfiguración postcristiana de la religión. Lizarra: Verbo Divino.

- , (1998). El discurso religioso de la modernidad. Habermas y la religión. Barcelona: Anthropos.

Mancinas-Chávez, R. (2016). Fundamentos teóricos de Estructura de la Información. Tenerife: Sociedad Latina de Comunicación Social.

Martínez, M. (2008). Inmigración, discurso y medios de comunicación. Alicante: Instituto Alicantino de Cultura Juan Gil-Albert.

Padrós, C. (2010). Pluralismo religioso y acceso a los medios de comunicación. La relevancia del derecho administrativo. In Consell de l'Audiovisual de Catalunya. Medios de comunicación y pluralismo religioso (151-186 or.). Barcelona. 
Sáez de la Fuente, I. (2002). El movimiento de liberación nacional vasco, una religión de sustitución. Bilbo: DDB.

Ruiz Vieytez, E. J. (Arg.) (2010). Pluralidades latentes: Minorías religiosas en el Paísvasco. Bartzelona: Icaria.

Ruiz Vieytez, E. J. (Arg.) (2011). La diversidad religiosa en el País Vasco: Nuevos retos sociales y culturales para las políticas públicas. Bilbo: Deustuko Unibertsitatea.

Taylor, Ch. (2007). A secular Age. Massachusetts: Havard University Press.

Taylor, Ch. Maclure, J. Hernández, M. (2010). Laicidad y libertad de conciencia. Madrid: Alianza.

Tarquis, P., Minorías religiosas en los medios de comunicación. In Protestante Digital 200905-24, eskuragarri dago: http://protestantedigital.com/magacin/11102/Minorias_religiosas_en_los_medios_de_comunicacion. Kontsultaren eguna: 2016-05-25.

UNESCO (1983). Conclusiones de la cuarta reunión consultiva de organizaciones internacionales y regionales de periodistas. Paris.

Urrutia, M. (2015). El “último” Habermas. La religión en el ámbito público de las religiones modernas. Inguruak, 59(2015), 66-88 or.

Vidal Fernández, F. (2005). Marco socicultural de la comunicación mediática Iglesia-sociedad. In VIDAL Vidal Fernández, F. - González-Carvajal, L. (Arg.). Medios de comunicación y religión en España. Una investigación sobre el estado de la comunicación mediática Iglesia-sociedad (10-72 or). Madril, SM. 